Davidson, L. S. P. \& Girdwood, R. H. (I95I a). Lancet, 260, 722.

Davidson, L. S. P. \& Girdwood, R. H. (I95 I b). Lancet, 26I, 1 I93.

Day, P. L. \& Totter, J. R. (1948). F. Nutrit. 36, 803.

Dinning, J. S., Keith, C. K. \& Day, P. L. (I95I). F. biol. Chem. 189, 515.

Ford, J. E. (r952). Brit. Y. Nutrit. 6, 324.

Girdwood, R. H. (1952a). Blood. 7,77.

Girdwood, R. H. (1952b). Biochem. F. (In the Press.)

Hausmann, K. (1949). Lancet, 257, 962.

Heinle, R. W., Welch, A. D., George, W. L., Epstein, M. \& Pritchard, J. A. (1947). F. Lab. clin. Med. 32, 1398.

Heinle, R. W., Welch, A. D. \& Pritchard, J. A. (1948). 7. Lab. clin. Med. 33, 1647.

Holly, R. G. (195I). Proc. Soc. exp. Biol., N.Y., 78, 238.

Horrigan, D., Jarrold, T. \& Vilter, R. W. (I95I). F. clin. Invest. 30, $3 \mathrm{r}$.

Jarrold, T., Horrigan, D., Thompson, C. \& Vilter, R. W. (1951). Science, 113, 688.

Lajtha, L. G. (1950). Clin. Sci. 9, 287.

Machlin, L. J., Denton, C. A. \& Bird, H. R. (1951). Fed. Proc. 1o, 388.

May, C. D., Nelson, E. N., Lowe, C. U. \& Salmon, R. J. (1950). Amer. F. Dis. Child. 80, x9r.

Mollin, D. L. \& Ross, G. I. M. (1951). Brit. med. F. ii, 293.

Nichol, C. A. \& Welch, A. D. (1950). Proc. Soc. exp. Biol., N.Y., 74, 403.

Oginsky, E. L. (1950). Arch. Biochem. 26, 327.

Robinson, F. A. (I95I). The Vitamin B Complex. London: Chapman and Hall.

Rusznyák, St, Löwinger, S. \& Lajtha, L. (1947). Nature, Lond., 160, 757.

Sauberlich, H. E. \& Baumann, C. A. (1948). F. biol. Chem. 176, 165 .

Smith, E. L. (1952). Brit. Y. Nutrit. 6, 295.

Stokes, J. L. (1944). F. Bact. 48, 201.

Strauss, M. B. \& Castle, W. B. (1932). Lancet, 223, I I I.

Suárez, R. M., Welch, A. D., Heinle, R. W., Suárez, R. M. Jr \& Nelson, E. M. (1946). F. Lab. clin. Med. 3I, 1294 .

Swendseid, M. E., Bethell, F. H. \& Ackermann, W. W. (195I). F. biol. Chem. 190, 791.

Ungley, C. C. (1951). Lancet, 24I, 1067.

Vilter, R. W., Horrigan, D., Mueller, J. F., Jarrold, T., Vilter, C. F., Hawkins, V. \& Seaman, A. (1950). Blood, 5,695 .

Wills, L., Clutterbuck, P. W. \& Evans, B. D. F. (1937). Lancet, 232, 3 II.

Wills, L. \& Evans, B. D. F. (1938). Lancet, 235, 416.

Wills, L. \& Stewart, A. (1935). Brit. F. exp. Path. 16, 444.

Wright, L. D., Skeggs, H. R. \& Huff, J. W. (1948). F. biol. Chem. r75, 475.

\title{
The Microbiological Assay of Vitamin $B_{12}$
}

\section{By J. E. Ford, National Institute for Research in Dairying, University of Reading}

The literature on the microbiological assay of vitamin $B_{12}$ is large and growing. Those familiar with microbiological techniques realize their limitations, but there is a danger that the apparent ease with which the tests can be carried out may encourage uncritical acceptance of the spate of results now appearing. An object of this paper is to show some of the difficulties that may be involved in the assay of vitamin $B_{12}$.

To begin with there are the ever-present fundamental problems of specificity of test and completeness of extraction. There is next the problem of the total extraction and measurement as vitamin $B_{12}$ of the series of related substances, all active microbiologically, that may be present in natural products, and that are distinguished from vitamin $B_{12}$ only by the replacement of the cyano-group by a variety of complex-bound anions (Brink, Kuehl \& Folkers, 1950; Kaczka, Wolf, Kuehl \& Folkers, 1950; Smith, 1948; Smith, Fantes, Ball, Ireland, Waller, Emery, Anslow \& Walker, I95I; Pierce, Page, Stokstad \& Jukes, 1949; Wijmenga, Veer \& Lens, 1950).

A further problem arises from the presence in some natural materials of other 
substances also related to vitamin $\mathbf{B}_{\mathbf{1 2}}$ but differently active for different assay organisms. They are not in the strict sense cobalamins and cannot be converted to vitamin $\mathrm{B}_{12}$ by treatment with cyanide (Coates, Ford, Harrison, Kon, Porter, Cuthbertson \& Pegler, I951; Coates, Ford, Harrison, Kon \& Porter, 1952; Ford, Kon \& Porter, I951; Ford \& Porter, 1952; Pfiffner, Calkins, Peterson, Bird, McGlohon \& Stipek, r95I; Wijmenga, I95I).

Finally, vitamin $B_{12}$ may also be present in some natural materials in a microbiologically inactive, 'bound' form (Bird \& Hoevet, I951; Smith, r950-I ; Meyer, Eppstein, Bethell \& Hall, 1950; Shaw, 1950; Ternberg \& Eakin, 1949).

It will be helpful to begin with a brief summary of some of the more commonly used microbiological methods.

\section{The lactobacilli as test organisms}

Under specified conditions, several of the lactic-acid bacteria require vitamin $B_{12}$. Of these, strains of Lactobacillus leichmannii and $L b$. lactis are widely used to assay the vitamin. The requirement for vitamin $B_{12}$ is not specific, in the sense that in the nutrition of these organisms certain nucleic-acid derivatives or deoxyribonucleic acid can replace, or stimulate the response to, vitamin $B_{12}$. The effects of these substances can, however, be minimized and often altogether eliminated, particularly in tube assays, by the use of appropriate techniques (see review by Snell \& Wright, I950 and Skeggs, Nepple, Valentik, Huff \& Wright, r950).

Vitamin $B_{12 b}$, one of the cobalamins present in natural materials, is readily inactivated for Lb. leichmannii on heating with the assay medium (cf. Soars \& Hendlin, 195 $I$ ) and may thus be lost in the process of measurement. Vitamin $B_{12 b}$ is readily converted into vitamin $B_{12}$ by treatment with cyanide (Brink et al. I950; Ellis, Petrow, Beaven, Holiday \& Johnson, I950; Veer, Edelhausen, Wijmenga \& Lens, I950) and the presence of minute amounts of cyanide prevents inactivation of vitamin $\mathrm{B}_{12 b}$ on heating with the assay medium, apparently by converting it to the stable vitamin $B_{12}$ (Cooperman, Drucker \& Tabenkin, 1951 ; Soars \& Hendlin, 1951). Cooperman et al. found with some products that only with media containing cyanide did $L b$. lactis assays agree with those by $L b$. leichmannii.

\section{Assays with Bacterium coli}

A mutant of Bact. coli requiring vitamin $\mathrm{B}_{12}$ is now increasingly used in a plate method perfected by workers at the Glaxo Laboratories (Bessell, Harrison \& Lees, I950; Cuthbertson, Pegler \& Lloyd, I95 I ; Harrison, Lees \& Wood, I95 I). The method is speedy and simple in operation and allows large numbers of assays to be carried out on a routine basis. It is subject to interference by methionine and to a lesser extent by other substances, but in general such interference is readily detected from the appearance of the zones of exhibition.

Burkholder (I95I) has described the use of this organism in a tube assay and reported good agreement between assays of a number of substances with it and with Euglena gracilis. This tube-assay technique is more sensitive than the plate method, which is best suited to the assay of higher-potency materials and extracts. 
Assays with Euglena gracilis

The high sensitivity and apparent specificity of Euglena gracilis as compared with other assay organisms (Hutner, Provasoli, Stokstad, Hoffmann, Belt, Franklin \& Jukes, 1949; Picken \& Bauriedel, 1950) has recommended its use with low-potency materials. Robbins, Hervey \& Stebbins (1950, 1951) have used it to measure the vitamin $B_{12}$ content of a wide range of natural materials, Ross (I950) for body fluids and liver extracts, but Picken \& Bauriedel (1950) found the method satisfactory only for the assay of relatively pure preparations. They described a method of using the organism, together with $L b$. leichmannii, in comparative bioautographic studies of vitamin $\mathrm{B}_{12}$ and related growth factors.

\section{Experience at Shinfield}

It has been generally accepted that these three types of organism can be used for the measurement of vitamin $B_{12}$ itself, and for some time now we have been using all three for work in our laboratory. We soon observed, however, that they respond differently to certain vitamin $B_{12}$-like factors, and we now use them in conjunction as a means of differentiation between these factors.

For assays with $L b$. leichmannii our method and medium are essentially as described by Skeggs et al. (1950) but with certain minor modifications in technique. In our experience this method measures in a reproducible fashion those alkali-labile substances in cyanide extracts of a wide variety of natural materials active for $L b$. leichmannii.

Our Bact. coli method is that of the Glaxo workers (Bessell et al. 1950; Cuthbertson et al. 195 I ; Harrison et al. 1951). With exceptions discussed below, we find broad similarity between results obtained with Bact. coli and Lb. leichmannii, and for certain crude and refined liver extracts agreement is good.

For the Euglena gracilis assays we use a technique based on that of Hutner et al. (1949). Results obtained for liver extracts agree broadly with those obtained with Bact. coli and Lb. leichmannii, but in general reproducibility is not satisfactory. In our hands the method has so far proved incapable of precisely measuring the vitamin $B_{12}$ activities of liver preparations, fish and whale products and gut contents and faeces. We have used the method allied with chromatography to indicate qualitatively the presence of vitamin $B_{12}$ activity in extracts.

Properties of some microbiologically active substances related to vitamin $B_{12}$

Natural materials may contain substances of the vitamin $B_{12}$ group active for one or more assay organisms (Coates, Ford, Harrison, Kon \& Porter, 1952; Ford et al. I95 I Ford \& Porter, I952; Kaczka et al. 1950; Smith et al. 195 I; Pfiffner et al. 195 I; Pierce et al. I949; Tarr, 195 I; Wijmenga, 1951). Further compounds closely related to vitamin $B_{12}$ have been prepared in the laboratory (Cooley, Ellis, Petrow, Beaven, Holiday \& Johnson, 195I; Kaczka et al. 1950; Smith et al. 195I). Though most of these substances can be converted to vitamin $B_{12}$ by the action of cyanide, we have found in calf gut-contents and faeces, in addition to vitamin $B_{12}$, three substances, provisionally described as fractions $A, B$ and $C$, related to vitamin $B_{12}$ but having widely different activities for different assay organisms, and not convertible 
by cyanide (Coates, Ford, Harrison, Kon \& Porter, 1952; Ford et al. 1951; Ford \& Porter, 1952). Fractions $A$ and $B$ are red, cobalt-containing pigments. Fraction $\mathrm{C}$ is found in calf faeces but has not yet been isolated from this source. We have prepared it by growing Bact. coli in a vitamin $B_{12}$-free medium supplemented with fraction $B$. The vitamin $B_{12}$ activity of extracts of the harvested cells was in the form of fraction $C$. Both fraction $A$ and vitamin $B_{12}$ were recovered largely unchanged after such passage through Bact. coli.

Fraction $\mathrm{A}$ is about as active for Bact. coli and Euglena gracilis as vitamin $\mathrm{B}_{\mathbf{1 2}}$. It is the most abundant active component in cyanide extracts of calf faeces and is approximately five times more active for Bact. coli and Euglena gracilis than for $L b$. leichmannii. Modification of the Lb. leichmannii assay-medium by omission of thiomalic acid and inclusion of sodium cyanide (cf. Soars \& Hendlin, I95 I) results in an apparent marked increase in the activity of fraction $A$ relative to vitamin $B_{12}$.

Fraction $B$ is probably as active for Bact. coli as vitamin $B_{12}$, but it has less than $\frac{1}{2000}$ of this activity for both $L b$. leichmannii and Euglena gracilis, and may be quite inactive for them. There is marked non-parallelism in the Bact. coli assay of this substance in terms of vitamin $\mathrm{B}_{12}$.

As far as we can judge, fraction $\mathrm{C}$ is as active for Bact. coli as fraction $\mathrm{B}$ and in crude extracts has about one-fifteenth this activity for $L b$. leichmannii.

Fractions $\mathrm{B}$ and $\mathrm{C}$ produce similar and characteristic zones of exhibition on Bact. coli plates. They are less sharply defined than those characteristic of fraction $A$ and vitamin $B_{12}$.

We have prepared a derivative of fraction $A$ apparently analogous to vitamin $B_{12 b}$ (Ford \& Porter, 1952). It may well be that further compounds exist, related to fractions $A, B$ or $C$ in the same way as the cobalamin series is related to vitamin $B_{12}$.

Cyanide treatment of these three fractions had no effect on their chromatographic behaviour or on their various microbiological potencies.

Fractions $\mathrm{A}$ and $\mathrm{B}$ are inactive for the chick when given in the diet, but fraction $\mathrm{A}$ is active by injection, and on clinical test was shown to be about as active as vitamin $\mathbf{B}_{12}$ in a single case of pernicious anaemia (Coates, Ford, Harrison, Kon \& Porter, 1952).

Pfiffner et al. (195 I) have isolated a rumen organism that in anaerobic fermentation produced a mixture of cobalt-containing pigments of the vitamin $\mathbf{B}_{12}$ group. They crystallized two of these substances, which were active for $L b$. leichmannii and $L b$. lactis but inactive in chick and rat tests.

Wijmenga (I95I) obtained a compound, vitamin $B_{12 m}$, from the faeces of pigs, horses and cattle. Its absorption spectrum was similar to that of vitamin $\mathrm{B}_{12}$, but it was slower-moving on paper chromatograms, and on microbiological assay with $L b$. leichmannii had only about half the activity of vitamin $\mathrm{B}_{12}$. Vitamin $\mathrm{B}_{12 m}$ is a cyano-complex, and strong illumination of a solution in $0.001 \mathrm{~N}-\mathrm{H}_{2} \mathrm{SO}_{4}$ gave rise to a substance of smaller $R_{F}$ value. This derivative was designated vitamin $\mathrm{B}_{12 m b}$.

Another substance, 'factor WR', was isolated from liver. Its absorption spectrum coincided with that of vitamin $B_{12}$, but it behaved very differently in paper partitionchromatography, and had only $40 \%$ of the microbiological activity (Lb. leichmannii) of vitamin $\mathrm{B}_{12}$. 
Effect of cyanide in facilitating extraction of vitamin $B_{12}$-active substances from natural materials

De Heus \& De Man (195I) have measured microbiologically the vitamin $B_{12}$ potencies of a number of substances extracted in the presence and absence of cyanide. In several instances they obtained much higher results with cyanide. In our experience cyanide facilitates extraction of the vitamin $B_{12}$-active components of gut contents and faeces, and gives higher and more reproducible results than those obtained without cyanide. Cyanide treatment did not increase the potencies of extracts, whereas its addition before extraction gave extracts of greatly increased potencies (Coates, Ford et al. 1951).

Wijmenga et al. (1950) showed that cyanide can replace proteolytic enzymes in the extraction of vitamin $B_{12}$ from liver, as it apparently removes a protein or peptide group, originally linked to the vitamin $B_{12}$ molecule. We have compared different methods of extracting vitamin $B_{12}$ from pig livers and found that steaming or autoclaving the homogenized livers with buffer at $\mathrm{pH} 5.5$ in the presence of cyanide was as effective, as judged by $L b$. leichmannii assay, as was autolysis followed by digestion at $65^{\circ}$ with cyanide-activated papain. Bact. coli assays of the papain digests were unsatisfactory because of the large amounts of interfering substances present. No such interference was found with extracts prepared by the other methods, and with these extracts the two methods of assay gave similar results.

\section{Assay of preparations containing mixtures of active substances that are not readily converted to vitamin $\mathrm{B}_{12}$ on cyanide treatment}

To assay preparations containing mixtures of active substances, it may be necessary to fractionate and assay the substances separately against appropriate standards, and chromatographic methods have obvious applications to this end. We have described a technique for the rapid separation on paper chromatograms of the vitamin $B_{12}$-active substances in gut contents and faeces (Ford et al. 195 I). We have used it to study the increase in the vitamin $B_{12}$ potency of calf faeces following incubation, shown by chick tests. The microbiological potency for Lb. leichmannii changed little on incubation, whereas potency for Bact. coli diminished. We found that incubation resulted in a marked increase in the vitamin $B_{12}$ component and the disappearance of a proportion of the activity contributed by other factors, in particular fraction $A$. This evidence suggests a possible explanation of the discrepancies between chick and microbiological assays, and of the increased potency for chicks after incubation.

\section{'Binding' of vitamin $\mathrm{B}_{12}$}

Some natural materials have the property of apparently combining with vitamin $\mathrm{B}_{12}$ and making it unavailable to assay micro-organisms (Bird \& Hoevet, 1951; Meyer et al. I950; Shaw, I950; Ternberg \& Eakin, I949). Sow's milk, for example, ties up considerable amounts of added vitamin $B_{12}$. The binding factor is not present in ultra-filtrates of sow's milk, and vitamin $B_{12}$ added to the milk becomes not ultrafiltrable. The apparent inhibition of growth of the assay organisms is overcome by the 
addition of vitamin $B_{12}$ in excess of about $0.05 \mu \mathrm{g} / \mathrm{ml}$. milk. The binding property is not destroyed, nor is added vitamin $B_{12}$ released, on autoclaving the milk for $15 \mathrm{~min}$ at $120^{\circ}$. Digestion with cyanide-activated papain, or autoclaving in the presence of a trace of cyanide, however, destroyed the 'binding' property of the milk and released added vitamin $B_{12}$ (Gregory, Ford \& Kon, 1952).

\section{Conclusions}

The non-specificity of available techniques of microbiological assay can complicate their use with some natural materials that may contain substances related to vitamin $B_{12}$, but differently active for different micro-organisms. It is possible, however, that these substances are less readily utilized by higher animals than is vitamin $B_{12}$ itself and that the assay of animal tissues may therefore present fewer problems of nonspecificity than that of fermentation products.

The use of Bact. coli in bioautographic techniques offers a ready means of identifying at least three substances related to vitamin $B_{12}$ that may be encountered in cyanidetreated extracts of natural materials. The presence of cyanide can facilitate the extraction of vitamin $B_{12}$-active substances from natural materials and simplify their measurement.

When microbiological assays are used to assess the value of foods for man or beast, it should be borne in mind that the response of micro-organisms to any nutrient as present in natural materials is not necessarily that of higher animals and, as with all assays, the question turns on the purpose for which the assay is carried out (Coates, Ford, Harrison, Kon, Shepheard \& Wilby, 1952).

Reports of marked discrepancies between results of biological and microbiological assays of vitamin $B_{12}$ and related substances (Coates, Harrison \& Kon, 1951; Combs, Carlson, Miller, Peeler, Norris \& Heuser, 1950; Lewis, Tappan \& Elvehjem, 1950; Pfiffner et al. 195I) further emphasize the need for a biological check before interpreting the results of microbiological assays in terms of animal requirements.

With microbiological assays of vitamin $B_{12}$ it appears that the fullest particulars of methods of extraction and assays, with data on recovery tests and possibly also the protocols of a typical assay, may be necessary for the interpretation of published findings. To quote Harris (1949), 'It is essential that workers reporting the results of vitamin determinations should not be content with giving merely a numerical value, but should state also the conditions employed for the assay'.

\section{REFERENCES}

Bessell, C. J., Harrison, E. \& Lees, K. A. (1950). Chem. E Ind. p. 561.

Bird, O. D. \& Hoevet, B. (r951). F. biol. Chem. rgo, 18r.

Brink, N. G., Kuehl, F. A. Jr. \& Folkers, K. (1950). Science, Ir2, 354.

Burkholder, P. R. (1951). Science, r14, 459.

Coates, M. E., Ford, J. E., Harrison, G. F., Kon, S. K. \& Porter, J. W. G. (1952). Biochem. F. 5I, vi.

Coates, M. E., Ford, J. E., Harrison, G. F., Kon, S. K., Porter, J. W. G., Cuthbertson, W. F. J. \& Pegler, H. F. (195I). Biochem. F. 49, lxvii.

Coates, M. E., Ford, J. E., Harrison, G. F., Kon, S. K., Shepheard, E. E. \& Wilby, F. W. (1952). Brit. F. Nutrit. 6, 75 .

Coates, M. E., Harrison, G. F. \& Kon, S. K. (1951). Analyst, 76, 146. 
Combs, G. F., Carlson, C. W., Miller, R. F., Peeler, H. T., Norris, L. C. \& Heuser, G. F. (1950). 7. biol. Chem. 182, 727.

Cooley, G., Ellis, B., Petrow, V., Beaven, G. H., Holiday, E. R. \& Johnson, E. A. (1951). F. Pharm. Pharmacol. 3, 271.

Cooperman, J. M., Drucker, R. \& Tabenkin, B. (1951). J. biol. Chem. I9I, I35.

Cuthbertson, W. F. J., Pegler, H. F. \& Lloyd, J. T. (I95I). Analyst, 76, 333.

De Heus, J. G. \& De Man, T. J. (195r). Voeding, 12, 36r.

Ellis, B., Petrow, V., Beaven, G. H., Holiday, E. R. \& Johnson, E. A. (1950). F. Pharm. Pharmacol. 2, 735.

Ford, J. E., Kon, S. K. \& Porter, J. W. G. (1951). Biochem. F. 50, ix.

Ford, J. E. \& Porter, J. W. G. (1952). Biochem. F. 51, v.

Gregory, M. E., Ford, J. E. \& Kon, S. K. (1952). Biochem. F. 5r, xxix.

Harris, L. J. (1949). Brit. F. Nutrit. 2, 362.

Harrison, E., Lees, K. A. \& Wood, F. (1951). Analyst, 76, 696.

Hutner, S. H., Provasoli, L., Stokstad, E. L. R., Hoffmann, C. E., Belt, M., Franklin, A. L. \& Jukes, T. H. (1949). Proc. Soc. exp. Biol., N.Y., 70, 118.

Kaczka, E., Wolf, D. E., Kuehl, F. A. Jr \& Folkers, K. (1950). Science, r12, 354.

Lewis, U. J., Tappan, D. U. \& Elvehjem, C. A. (1950). Abstr. Pap. Amer. chem. Soc. 118th Mtg, p. $72 \mathrm{C}$.

Meyer, C. E., Eppstein, S. H., Bethell, F. H. \& Hall, B. E. (1950). Fed. Proc. 9, 205.

Pfiffner, J. J., Calkins, D. J., Peterson, R. C., Bird, O. D., McGlohon, V. \& Stipek, R. W. (I95I) Abstr. Pap. Amer. Chem. Soc. 120th Mtg, p. 22 C.

Picken, J. C. \& Bauriedel, W. R. (1950). Proc. Soc. exp. Biol., N.Y., 75, 51 1.

Pierce, J. V., Page, A. C. Jr., Stockstad, E. L. R. \& Jukes, T. H. (I949). F. Amer. chem. Soc. 7r, 2952.

Robbins, W. J., Hervey, A. \& Stebbins, M. E. (1950). Bull. Torrey bot. Cl. 77, 423.

Robbins, W. J., Hervey, A. \& Stebbins, M. E. (1951). Bull. Torrey bot. Cl. 78, 363.

Ross, G. I. M. (1950). Nature, Lond., 166, 270.

Shaw, G. E. (1950). Biochem. Y. 47, xxxv.

Skeggs, H. R., Nepple, H. M., Valentik, K. A., Huff, J. W. \& Wright, L. D. (1950). F. biol. Chem. 184,211 .

Smith, E. L. (1948). Nature, Lond., 162, 144.

Smith, E. L. (1950-1). Nutr. Abstr. Rev. 20, 795.

Smith, E. L., Fantes, K. H., Ball, S., Ireland, D. M., Waller, J. G., Emery, W. B., Anslow, W. K. \& Walker, A. D. (195I). Biochem. F. 48, I.

Snell, E. E. \& Wright, L. D. (1950). Ann. Rev. Biochem. 19, 277.

Soars, M. H. \& Hendlin, D. (195I). F. Bact. 62, 15.

Tarr, H. L. A. (195I). Canad. $\mathcal{~}$. Tech. 29, 391.

Ternberg, J. L. \& Eakin, R. E. (1949). F. Amer. chem. Soc. 7I, 3858.

Veer, W. L. C., Edelhausen, J. H., Wijmenga, H. G. \& Lens, J. (1950). Biochim. biophys. Acta, 6,225 .

Wijmenga, H. G. (195I). Onderzoekingen over vitamine $B_{12}$ en verwante factoren. Doctorate Thesis, University of Utrecht.

Wijmenga, H. G., Veer, W. L. C. \& Lens, J. (1950). Biochim. biophys. Acta, 6, 229.

\section{The Nutritional Significance of the Animal Protein Factor and Antibiotics}

\section{By W. F. J. Cuthbertson, Glaxo Laboratories Ltd., Greenford, Middlesex}

Diets composed wholly of vegetable materials have for some time been known to be inadequate for the growth of chicks (Hammond \& Titus, r944a, $b$; Rubin \& Bird, 1946) or rats (Zucker \& Zucker, 1948), even when supplemented with all the previously recognized vitamins. The factor (or group of factors) essential for the growth of animals maintained on these diets came to be called the 'animal protein factor' (APF) and was soon shown, though not a protein, to be present in materials of animal origin, e.g. milk, meat, liver, fish meal and cow manure (Rubin, Groschke \& Bird, 1947; Bird, Rubin \& Groschke, 1948).

The growth of chicks and pigs on wholly vegetable diets was greatly improved by administration of vitamin $\mathrm{B}_{12}$ (Ott, Rickes \& Wood, 1948; Hogan \& Anderson, 1949), 